\title{
BM] Global Health Implementing sustainable primary healthcare reforms: strategies from Costa Rica
}

\author{
Lauren Spigel (1) ,' Madeline Pesec, ${ }^{1,2}$ Oscar Villegas del Carpio, ${ }^{3}$ \\ Hannah L Ratcliffe (D) , ${ }^{1}$ Jorge Arturo Jiménez Brizuela, ${ }^{4}$ Andrés Madriz Montero, ${ }^{5}$ \\ Eduardo Zamora Méndez, ${ }^{4}$ Dan Schwarz, ${ }^{1,6}$ Asaf Bitton, ${ }^{1,7}$ Lisa R Hirschhorn (D) ${ }^{1,8}$
}

\begin{abstract}
To cite: Spigel L, Pesec M, Villegas del Carpio 0, et al. Implementing sustainable primary healthcare reforms: strategies from Costa Rica. BMJ Global Health 2020;5:e002674. doi:10.1136/ bmjgh-2020-002674
\end{abstract}

Handling editor Seye Abimbola

- Additional material is published online only. To view, please visit the journal online (http://dx.doi.org/10.1136/ bmjgh-2020-002674).

Received 16 April 2020 Revised 6 July 2020 Accepted 7 July 2020

\section{ABSTRACT}

As the world strives to achieve universal health coverage by 2030 , countries must build robust healthcare systems founded on strong primary healthcare (PHC). In order to strengthen PHC, country governments need actionable guidance about how to implement health reform. Costa Rica is an example of a country that has taken concrete steps towards successfully improving PHC over the last two decades. In the 1990s, Costa Rica implemented three key reforms: governance restructuring, geographic empanelment, and multidisciplinary teams. To understand how Costa Rica implemented these reforms, we conducted a process evaluation based on a validated implementation science framework. We interviewed 39 key informants from across Costa Rica's healthcare system in order to understand how these reforms were implemented. Using the Exploration Preparation Implementation Sustainment (EPIS) framework, we coded the results to identify Costa Rica's key implementation strategies and explore underlying reasons for Costa Rica's success as well as ongoing challenges. We found that Costa Rica implemented PHC reforms through strong leadership, a compelling vision and deliberate implementation strategies such as building on existing knowledge, resources and infrastructure; bringing together key stakeholders and engaging deeply with communities. These reforms have led to dramatic improvements in health outcomes in the past 25 years. Our in-depth analysis of Costa Rica's specific implementation strategies offers tangible lessons and examples for other countries as they navigate the important but difficult work of strengthening PHC.

\section{INTRODUCTION}

(C) Author(s) (or their employer(s)) 2020. Re-use permitted under CC BY-NC. No commercial re-use. See rights and permissions. Published by BMJ.

For numbered affiliations see end of article.

\section{Correspondence to} Dr Lisa R Hirschhorn; lisa.hirschhorn@northwestern. edu
In 2019, the United Nations reaffirmed their landmark declaration to achieve universal health coverage (UHC) by $2030,{ }^{1}$ a bold step towards achieving Sustainable Development Goal Three. ${ }^{23}$ Countries must build robust healthcare systems founded on primary healthcare (PHC) to ensure access to quality preventative and curative healthcare. ${ }^{4-13}$ Over 134 nations committed to making PHC the cornerstone of their health system through the 2018 Declaration on PHC in Astana. ${ }^{14}$

\section{Summary}

- The global community is increasingly aligned on the idea that high-performing primary healthcare (PHC) is essential for achieving universal health coverage and Sustainable Development Goal Three.

- Costa Rica has taken concrete steps towards improving PHC through several health reforms in the 1990s, including governance restructuring, geographic empanelment and multidisciplinary teams.

- While previous research has described these reforms, our in-depth analysis identifies specific implementation strategies that Costa Rica used to implement the reforms nationwide, including developing a compelling vision, building on existing resources and engaging deeply with community.

- These strategies offer tangible lessons for other countries as they navigate the important but difficult work of strengthening PHC.

While leading health organisations, such as WHO and the World Organization of Family Doctors, have issued guidelines for best practice of $\mathrm{PHC},{ }^{13}$ countries also need tangible examples of how to improve PHC.

While many countries initially focused on improving only selective PHC services, Costa Rica, along with some other countries including Thailand, Brazil, Cuba, Ghana and Turkey, was an early adopter of a comprehensive primary care model more in line with the Declaration of Alma Ata and now codified in the Declaration of Astana. ${ }^{5}$ The Declaration of Astana describes the priorities of PHC as 'not simply health services at the primary care level (though that was important), but rather a health system model that acted also on the underlying social, economic and political causes of poor health'. ${ }^{145}$

The Costa Rican PHC reform builds on several PHC-strengthening efforts over three decades. In the 1970s, for example, the Ministry of Health $(\mathrm{MOH})$ expanded 
primary care and public health services to vulnerable populations, setting the foundation for comprehensive PHC in Costa Rica. ${ }^{16}{ }^{17}$ In the 1980 s, economic decline led to a defunding of MOH's initiatives and Costa Rica instead relied on private firms to provide health coverage for employees and their dependents, while others paid out-of-pocket for services. ${ }^{16}$ By the early 1990s, the Costa Rican government observed growing inefficiencies in the health system, caused by underfunding of PHC systems, uncoordinated patient flows leading to overcrowding in higher-level facilities and redundancies in the PHC system between the $\mathrm{MOH}$ and the Costa Rica Social Security Administration (CCSS). ${ }^{18} 19$ In response to these challenges, Costa Rica undertook a major reform in 1994 based on a PHC delivery model grounded in health equity, community participation and social determinants of health. Pesec et al recently described four essential reforms that contributed to Costa Rica's PHC strengthening: (1) governance restructuring, (2) multidisciplinary teams, (3) geographic empanelment and (4) measurement and reliable data feedback loops. ${ }^{17}$

While identifying the reforms and measuring health outcomes are essential for drawing actionable lessons from Costa Rica's example, countries looking to strengthen PHC also need information on how these reforms were implemented. ${ }^{20}$ We used an implementation science framework, Exploration, Preparation, Implementation and Sustainment (EPIS), which was developed to evaluate public health interventions. ${ }^{21}$ We used the EPIS framework to analyse and identify specific implementation strategies that Costa Rica used and key contextual factors which facilitated or hindered progress. We describe the implementation of three of reforms, with the measurement reform described in a separate manuscript (Pesec M, Ariadne Labs, personal communication, 2020). Understanding Costa Rica's implementation strategies and influencing contextual factors hold important lessons for policy makers who aim to build a PHC system grounded in community participation, social determinants of health and health equity.

Costa Rica's health outcomes in the 20 years since the PHC reforms are well-documented. ${ }^{16}{ }^{22-25}$ A middle-income country, Costa Rica now has the third highest life expectancy at birth in the Western Hemisphere (behind only Canada and Bermuda) at 80 years. ${ }^{26}$ Measures such as maternal mortality ratio (25 per 100000 live births), neonatal mortality rate (6 per 1000 live births) and under-five mortality rate (9 per 1000 live births) are some of the lowest among low-income and middle-income countries and have been declining since the reforms were implemented in the 1990s. ${ }^{26}$

We sampled 39 key informants (KI) from three of seven health regions in Costa Rica for qualitative in-depth, unstructured interviews between June and July 2017. KIs were first purposefully sampled based on their knowledge of the PHC model, current or previous position within the health system and geographic location. We then used snowball sampling to recruit other KIs identified as relevant to the areas of inquiry. KIs represented
Table 1 Key informant categories

\begin{tabular}{lc} 
Key informant categories & $\begin{array}{l}\text { Total } \\
\text { (N) }\end{array}$ \\
\hline $\begin{array}{l}\text { Costa Rican Social Security Administration (CCSS) } \\
\text { stakeholders }\end{array}$ & 15 \\
\multicolumn{1}{l}{ CCSS administrators } & 13 \\
\hline \multicolumn{1}{l}{ CCSS former directors } & 2 \\
Health area administrators & 11 \\
$\begin{array}{l}\text { Multidisciplinary team members known as Equipo } \\
\text { Básico de Atención integral en Salud (EBAIS:Basic } \\
\text { Integrated Care Team) }\end{array}$ & 6 \\
Academics (within Costa Rica) & 4 \\
Health region administrators & 3 \\
Total & 39 \\
\hline
\end{tabular}

EBAIS, Equipo Básico de Atención integral en Salud.

all levels of the health system (table 1 ). While we identify informants primarily as policymakers, 25 (64.1\%) KIs were also providers, and so were able to provide insights from more than one perspective. The number of interviews conducted was limited by time and resources. Verbal informed consent was obtained for each interview.

Interviews were conducted in-person at the KIs' place of work by one author (MP) in Spanish and lasted an average of $70 \mathrm{~min}$. Interviews were guided by the EPIS framework, an implementation science framework designed to understand implementation of evidencebased interventions (table 2). ${ }^{21}{ }^{27}$ When available, we triangulated perspectives from different actors involved in the reforms and did not attempt to reach saturation.

Interviews were audio recorded, transcribed and coded in Spanish by two authors (MP and LS) using an inductive and deductive approach in Dedoose software. An initial codebook was developed based on the EPIS framework and inductive codes were added as themes emerged. Each of the three reforms, ${ }^{17}$ the implementation strategies used and critical contextual factors that influenced decision-making were traced through each EPIS phase. Fifteen per cent of interviews were double coded until consistency was reached between coders. Coders reviewed codes weekly and reached consensus

\begin{tabular}{|c|c|}
\hline EPIS phase & Description \\
\hline Exploration & $\begin{array}{l}\text { Stakeholders determine that there is a } \\
\text { challenge that needs to be solved. }\end{array}$ \\
\hline Preparation & $\begin{array}{l}\text { Stakeholders choose evidence-based } \\
\text { practice(s) to solve the challenge. }\end{array}$ \\
\hline Implementation & $\begin{array}{l}\text { Stakeholders implement their evidence- } \\
\text { based practice(s). }\end{array}$ \\
\hline Sustainment & $\begin{array}{l}\text { Evidence-based practice is ingrained and } \\
\text { sustains over time. }\end{array}$ \\
\hline
\end{tabular}


through discussion. Discrepancies were resolved by additional authors (HR and LH).

\section{EXPLORATION}

The 1980s economic recession was devastating for the Costa Rican economy and health system. In the late 1980s, there was a growing understanding among policy-makers that quality and efficiency of PHC was weakening. Key health indicators were declining and there was growing patient dissatisfaction with PHC services. The $\mathrm{MOH}$ and the CCSS were both providing PHC functions, creating redundancies in the public system.

In response, the International Monetary Fund and the World Bank offered a Structural Adjustment Programme, requiring Costa Rica to reduce the size of its government expenditures in exchange for additional funding. Accordingly, Costa Rica laid off many of their government employees and reduced health and social services. Soon they saw problems, such as less potable water, undernourished children and a measles outbreak. In the wake of these challenges, individuals from the CCSS and the University of Costa Rica convened in the early 1990s to devise a new PHC model.

...These are activities that require people-to take care of the aqueducts, to add chlorine to make potable water, it's not easy, it's not a simple thing. The cafeterias in the schools, the health centers...they all require staff. (Former CCSS Director)

\section{PREPARATION}

CCSS leaders developed the new PHC model by adopting four strategies: (1) seek lessons from other countries, (2) seek lessons from Costa Rica's past, (3) define a compelling vision for a nationally developed PHC model and (4) obtain external donor funding for the nationally developed plan.

\section{Seek lessons from other countries}

Health leaders travelled abroad and reviewed published literature to learn from other countries' PHC models. This strategy helped them identify promising practices and inform critical decisions about how to adapt the practices, such as empanelment and multidisciplinary teams, to the Costa Rican context.

We went to Denmark and we saw how it worked. It was a wonder... we met every night...to make decisions about what we're going to do... and how are we going to do it all.

(Former CCSS Director)

\section{Seek lessons from Costa Rica's past}

Health leaders drew on lessons from Costa Rica's prior experience in PHC innovations, such as the Rural Health Programme, SILOS (Sistema Locales de Salud or Local Health Systems) and Hospital without Walls. ${ }^{17}$ Health leaders recognised that multidisciplinary teams, led by doctors, and geographic empanelment, were culturally appropriate methods for reaching their population with quality care and reducing health disparities. ${ }^{28}$

\section{Define a compelling vision and create a nationally developed PHC model}

Health leaders convened to define a vision for the new PHC model: to provide equitable, comprehensive healthcare, equally emphasising promotive, preventative and curative health services. This compelling vision was critical for building buy-in from diverse stakeholders. Based on the vision and learnings, health leaders developed a proposal for three PHC reforms, which are the focus of this study (table 3 ).

\section{Obtain external donor funding for the nationally developed plan}

Health leaders approached international donors with their proposal, but were met with pushback. For example, one donor thought it too costly to include a doctor on each EBAIS team, but the health leaders' compelling vision-supported by lessons learnt from past reforms in Costa Rica and elsewhere-enabled them to articulate their case.

What we want is to expand protection, expand coverage, improve quality, eliminate waiting lines. Without doctors you can't eliminate waiting lines...It is more expensive, of course! But if it is about improving, we have to invest more... (Former CCSS Director)

The World Bank and other multilateral organisations ultimately invested in the new model, including personnel costs, procurement of equipment and some construction of EBAIS clinics. While the CCSS provided some funding, they did not have to fund the entire reform.

\section{IMPLEMENTATION}

After obtaining funding, health leaders began the reforms through key implementation strategies (table 4).

\section{Governance restructuring}

Governance restructuring required clarifying the $\mathrm{MOH}$ and CCSS's relationships and the redistribution of human and financial resources. Historical animosity as well as different pay scales and benefit packages led to initial widespread resistance among staff. Leaders from both organisations employed four strategies to overcome these challenges: (1) create technical working groups (TWGs); (2) engage communities by high-level leadership; (3) sign a formal document of agreement and (4) foster professional relationships and build capacity in the new model.

\section{Create TWGs}

The CCSS director led a 'preparatory unit', which oversaw multiple TWGs led by experts from the $\mathrm{MOH}$ and CCSS. Teamwork fostered by TWGs was essential for decisionmaking and synchronising policies. Leadership commitment from $\mathrm{MOH}$ and CCSS facilitated this by allowing 
Table 3 Reforms identified for Costa Rica's PHC model

\begin{tabular}{|c|c|c|}
\hline Reform & Description & Illustrative quotes \\
\hline $\begin{array}{l}\text { Governance } \\
\text { restructuring }\end{array}$ & $\begin{array}{l}\text { Healthcare provision was restructured so that all healthcare } \\
\text { in the public sector (primary through tertiary) was provided } \\
\text { solely through the CCSS rather than both the } \mathrm{MOH} \text { and } \\
\text { CCSS, which streamlined the healthcare system. MOH was } \\
\text { responsible for stewardship of the healthcare system. }\end{array}$ & $\begin{array}{l}\text { 'Then we proposed an integration of the primary care services } \\
\text { that the CCSS had with the Ministry and eliminate duplication. } \\
\text { Instead of having Ministry of Health clinic and a CCSS clinic, let's } \\
\text { make one (clinic) for the entire community...' } \\
\text { (Former CCSS Director) }\end{array}$ \\
\hline $\begin{array}{l}\text { Geographic } \\
\text { empanelment }\end{array}$ & $\begin{array}{l}\text { The population was geographically empanelled, meaning } \\
\text { each household was assigned to a multidisciplinary } \\
\text { team (EBAIS) solely based on their geographic location. } \\
\text { Approximately } 4000 \text { people were empanelled to each team. } \\
\text { This supported the population's geographic access to PHC. } \\
\text { Administratively, Costa Rica's health system was divided into } \\
\text { seven health regions, which were further divided into health } \\
\text { areas. Health areas oversaw EBAIS clinics in communities. }\end{array}$ & $\begin{array}{l}\text { '...it was a tradition that came from } 1972, \text { to have the well- } \\
\text { defined health area, with the households identified, and each } \\
\text { household with the family health record in the archive, and the } \\
\text { rural health worker...took those files and visited house by house, } \\
\text { once or twice a year'. (Academic) }\end{array}$ \\
\hline $\begin{array}{l}\text { Multidisciplinary } \\
\text { teams (EBAIS) }\end{array}$ & $\begin{array}{l}\text { Multidisciplinary teams were the centre of the PHC model. } \\
\text { These teams, known as EBAIS, provided preventative } \\
\text { and curative services to their geographically empanelled } \\
\text { population. } \\
\text { Each EBAIS included the following team members, who } \\
\text { were trained in community-based medicine (see online } \\
\text { supplementary table A in appendix): } \\
\text { Doctor: consulted with patients for PHC delivery } \\
\text { Nurse assistant: conducted preconsults with patients and } \\
\text { educated patients about healthy lifestyles } \\
\text { Asistente Técnico en Atención Primaria (ATAP) or Primary } \\
\text { Care Technical Assistentmade home visits for preventive care } \\
\text { Registros Estadisticas de Salud (REDES) or Health } \\
\text { Statistics Records: managed medical records and patient } \\
\text { data } \\
\text { These teams worked together to provide integrated curative } \\
\text { and preventative care. For example, ATAPs provided } \\
\text { preventative care through home visits and referred sick } \\
\text { patients to doctors for curative care. Nurses played both } \\
\text { a curative and preventative role by assisting doctors in } \\
\text { clinical visits and educating patients on health conditions } \\
\text { and determinants. } \\
\text { EBAIS also had 'support teams' located at the health area } \\
\text { level. The support teams could include a family doctor, } \\
\text { nutritionist, social worker, nurse, pharmacist, microbiologist } \\
\text { and an orthodontist. Together with the EBAIS team, } \\
\text { they were known as the 'Local Health Team' (see online } \\
\text { supplementary table A in appendix). }\end{array}$ & $\begin{array}{l}\text { 'In the } 90 \text { 's, what was said was: How can we as a country } \\
\text { develop a public health strategy with a focus on public health that } \\
\text { emphasizes prevention and promotion, and addresses diseases, } \\
\text { of course, because you need to attend to what's urgent, } \\
\text { but whose emphasis will be primary care. So this (idea) was } \\
\text { consolidated into the EBAIS teams'. (Former CCSS Director) }\end{array}$ \\
\hline
\end{tabular}

CCSS, Costa Rica Social Security Administration; EBAIS, Equipo Básico de Atención integral en Salud; PHC, primary healthcare.

individuals to be 'pulled out of' their work to participate in the reform.

\section{Engage communities by high-level leadership}

Both institutions' unions were strong and vocally resistant to the reforms. The Vice Minister of Health led union negotiations, reflecting high-level commitment, which was felt to be vital to its success. Negotiations enabled staff to resolve areas of disagreement and buy into the reform.

\section{Sign a formal document of agreement}

Leaders from government, $\mathrm{MOH}$ and CCSS signed a document of agreement, formalising institutional ownership of the reform and fostering sustainability.

Foster professional relationships and build capacity in the new model

Training workshops were co-organised from both institutions, providing opportunities to come together and foster personal and professional relationships while being trained in the new model.

This (training) is when the people from the CCSS and the Ministry could come together, really, to make us aware that the change was positive for the country and for the people...All of the trouble that had existed between the two organisations was removed. (CCSS administrator)

\section{Geographic empanelment}

Health leaders employed three strategies to facilitate implementation: (1) create a TWG; (2) use existing resources and (3) engage communities. KIs reported that geographic empanelment was one of the most challenging reforms to implement, both technically (due to geographic diversity) and interpersonally. For example, the TWG had to understand pre-existing relationships between the communities that would ultimately be empanelled to the same EBAIS. Geographic empanelment was also a key strategy for reducing health disparities. $^{28}$ 


\begin{tabular}{|c|c|c|c|c|}
\hline \multirow[b]{2}{*}{$\begin{array}{l}\text { Implementation } \\
\text { strategy }\end{array}$} & \multirow[b]{2}{*}{ Description } & \multicolumn{3}{|l|}{ Reform } \\
\hline & & $\begin{array}{l}\text { Governance } \\
\text { restructuring }\end{array}$ & $\begin{array}{l}\text { Geographic } \\
\text { empanelment }\end{array}$ & $\begin{array}{l}\text { Multidisciplinary } \\
\text { teams }\end{array}$ \\
\hline $\begin{array}{l}\text { Create technical } \\
\text { working groups }\end{array}$ & $\begin{array}{l}\text { Multidisciplinary groups of key stakeholders met } \\
\text { to make decisions about each of the reforms. }\end{array}$ & $\bullet$ & $\bullet$ & $\bullet$ \\
\hline $\begin{array}{l}\text { Engage } \\
\text { communities }\end{array}$ & $\begin{array}{l}\text { Health leaders engaged communities at every } \\
\text { level during each stage of the reform. }\end{array}$ & $\bullet$ & $\bullet$ & $\bullet$ \\
\hline $\begin{array}{l}\text { Sign a formal } \\
\text { agreement }\end{array}$ & $\begin{array}{l}\text { Formal agreement between } \mathrm{MOH} \text { and CCSS } \\
\text { leaders solidified commitment to the model. }\end{array}$ & $\bullet$ & & \\
\hline $\begin{array}{l}\text { Foster professional } \\
\text { relationships }\end{array}$ & $\begin{array}{l}\text { Relationships between } \mathrm{MOH} \text { and CCSS staff } \\
\text { were intentionally fostered after governance } \\
\text { restructuring was final. }\end{array}$ & $\bullet$ & & \\
\hline Build capacity & $\begin{array}{l}\text { Health leaders prioritised training all health } \\
\text { personnel in the new model. }\end{array}$ & $\bullet$ & & $\bullet$ \\
\hline $\begin{array}{l}\text { Use existing } \\
\text { resources }\end{array}$ & $\begin{array}{l}\text { Whenever possible, health leaders used existing } \\
\text { resources to save time and build on existing } \\
\text { knowledge. }\end{array}$ & & $\bullet$ & $\bullet$ \\
\hline Apply an equity lens & $\begin{array}{l}\text { Health leaders implemented the new model by } \\
\text { prioritising the most vulnerable communities at } \\
\text { the outset of the programme. }\end{array}$ & & $\bullet$ & $\bullet$ \\
\hline
\end{tabular}

CCSS, Costa Rica Social Security Administration; $\mathrm{MOH}$, Ministry of Health; PHC, primary healthcare.

\section{Create a TWG}

A TWG was created at the central level to geographically empanel the population. The TWG was multidisciplinary, consisting of experts in population health and geography, from the MOH, CCSS and the University of Costa Rica. This strategy facilitated implementation by drawing on diverse areas of expertise to design the approach to geographic empanelment and gain acceptance.

Use existing resources: previously collected data Creating a system of geographic empanelment required data on the home locations of Costa Rica's population. TWGs used annual census data and previously drawn community maps to define each EBAIS catchment area. A local geographer was also consulted to ensure accuracy of the defined areas and to address geographic challenges such as natural boundaries and topography.

\section{Engage communities}

For some Costa Ricans, geographic empanelment represented a fundamental shift in the way they accessed care. The TWG travelled to communities across the country to discuss empanelment plans. While the travel was physically demanding, this strategy was important for fostering community buy-in for the model and understanding how to address challenges, such as communities who did not want to be linked together.

We had problems in several regions because people didn't like each other. They each wanted their own (EBAIS) and not join with another group. At the end, I convinced them...it wasn't easy. (CCSS administrator)

\section{Multidisciplinary teams (EBAIS)}

Health leaders employed five strategies to implement EBAIS: (1) create a TWG; (2) use existing resources; (3) build capacity; (4) apply an equity lens and (5) engage communities.

\section{Create a TWG}

Leaders from each profession within EBAIS, along with representatives from $\mathrm{MOH}$ and CCSS formed a TWG to problem-solve implementation challenges as the EBAIS teams were first introduced to communities, demonstrating a willingness to iterate on their processes.

In this group was the boss of the REDES, the boss of nursing, personnel from the Ministry and the CCSS... all of the bosses from all of the health professions because they had to change their entire way of doing things. This was a revolution! ...So this group met once a week to see progress and where they had problems. (CCSS administrator)

\section{Use existing resources: infrastructure}

When possible, CCSS transformed existing infrastructure into EBAIS clinics to save limited resources. This expedited implementation, but was not always successful. For example, some facilities did not adhere to all specifications of the Equal Opportunity Law for People with Disabilities and in some communities, new facility construction was required.

\section{Build capacity: EBAIS teams}

The formation of EBAIS teams changed the scope of practice for existing health workers. CCSS invested heavily in training all EBAIS teams in the full range of curative and 
preventative PHC services. While Costa Rica did not create any certification or specialisation for PHC clinicians, they required that all EBAIS doctors undergo re-training in community health, including epidemiology and community management. To increase efficiency and sustainability, eventually community health was integrated into the medical school curriculum so all medical students were trained in community medicine, which included a clinical component in the field with an EBAIS team. ATAPs, which were a new cadre, were trained for 1 year.

\section{Apply an equity lens}

The first EBAIS clinics were implemented in communities that were among the most socioeconomically vulnerable, based on existing socioeconomic data. This promoted equity by ensuring that the poorest communities had access to PHC.

\section{Engage communities}

To build community buy-in and trust in EBAIS teams, ATAPs were recruited from local communities and existing community health worker programmes, representing individuals with pre-existing relationships with the community. Communities that were interested in implementing EBAIS teams were also among those chosen for initial implementation. These communities would also serve as champions for future phases to generate buyin, especially among neighbouring communities that had been sceptical of the model. Once EBAIS teams were established, health areas led biannual community health needs assessments in conjunction with community members to ensure that EBAIS teams were responsive to community needs.

All of the people in the community come together (with) the people from work, and we all work together to formulate a list of problems. We have a specific methodology for this. And when we finish, we know what are the needs at this exact moment and we make a plan for that. (Health Area Administrator)

\section{Implementation challenge}

Achieving national EBAIS coverage took longer than planned due to limited resources and waning political will. This often led to overburdened clinics serving multiple patient panels, especially in urban settings. Associated challenges included equipment shortages, long wait times, health worker shortages and short appointment visits. Insufficient urban infrastructure has also been a major challenge, leading to diminished doctorpatient relationships and disrupted continuity of care. In addition, urban EBAIS have found it difficult to carry out health promotion and prevention among more transient populations (online supplementary table $\mathrm{B}$, appendix).

Table 5 Strategies for sustaining Costa Rica's PHC model over time

\begin{tabular}{ll}
\hline Strategies & Description \\
\hline Autonomy of CCSS & Since the CCSS is an autonomous organisation \\
& with its own financing system, it has insulated PHC \\
& delivery from politics and allowed the PHC model \\
to sustain through the changing priorities of political \\
leaders.
\end{tabular}

Illustrative quotes

'It has continuity. And even when another government comes in, this government doesn't have all of the power. Why? Because here (CCSS) there are seven (on the board of directors)... there are four people who are not with the government, so... here there's an equilibrium, let's say of interests, of forces'. (Health Area administrator)

Compelling vision for $\mathrm{PHC}$ model
The vision of the PHC model, to provide comprehensive preventative and curative services to all, was understood across stakeholders. This clear message helped form a new identity for PHC, ultimately generating widespread public support for the PHC model that has sustained over time.

$\begin{array}{ll}\begin{array}{l}\text { Use of data to generate } \\ \text { political will }\end{array} & \begin{array}{l}\text { Data were used to convince government leaders to } \\ \text { continue the PHC model. Ongoing data collection } \\ \text { and research ultimately demonstrated improved } \\ \text { health outcomes. The CCSS used this evidence } \\ \text { to advocate for the PHC model through political } \\ \text { turnover. }\end{array} \\ \text { Preservice training for EBAIS } & \begin{array}{l}\text { Integrating community-based medicine into the } \\ \text { medical school curriculum enabled sustainment } \\ \text { of the model to the next generation of medical } \\ \text { students. Additionally, a mandatory year of service } \\ \text { is completed by each newly graduated medical } \\ \text { student before any specialty training is pursued. } \\ \text { This year is spent providing primary care in a rural } \\ \text { and underserved area of the country, engraining } \\ \text { primary care principles and practice into each Costa } \\ \text { Rican physician. }\end{array}\end{array}$

'Primary health care began to have a little of its own identity. They began to see that primary level of care could be something really interesting, really useful'. (CCSS stakeholder)

'In 1998 what happened? Some studies began to come out, some that I did, others that others did, that began to show hard data that this was working, and that was what prevented this from being cut... with the government that entered the presidency in 1998. (Academic)

'One (education block) is community medicine, so the student internists come here and they have to go out (into the community) with the ATAPs and see what they do and see what the doctors do'. (Health Area administrator)

CCSS, Costa Rica Social Security Administration; EBAIS, Equipo Básico de Atención integral en Salud; PHC, primary healthcare. 


\section{SUSTAINMENT}

The essential components of Costa Rica's PHC model have sustained for over 25 years, with EBAIS clinics covering $94 \%$ of the population by $2012 .{ }^{29}{ }^{30}$ Four strategies were identified as facilitating sustainment: (1) autonomy of CCSS; (2) compelling national vision for the model; (3) use of data to generate political will and (4) preservice training for EBAIS doctors (table 5). External accountability created by the World Bank loan also facilitated sustainment.

\section{CONCLUSION}

In the context of increasing global attention to strengthening PHC systems to achieve UHC, we described how Costa Rican health leaders designed and implemented three key reforms-governance restructuring, geographic empanelment and multidisciplinary teamsto improve their PHC services.

We found that Costa Rican health leadership undertook each EPIS phase with intention, ensuring that the model reflected their core values. Their success has also been driven by a willingness to learn from domestic and international experiences before and during implementation, as well as their deep engagement with key stakeholders (from local communities through the national level). Importantly, they adapted regional and global promising practices to their specific cultural, political and economic context. We found that this careful work during the first three EPIS phases contributed to Costa Rica's ability to sustain the PHC model for over 25 years.

Costa Rica's implementation strategies are consistent with principles of change management and systemfocused quality improvement literature. ${ }^{31-34}$ Deming's Management Principles, the Juran Quality Trilogy and Kotter's Eight-Stage Process feature vision-setting, strong leadership, community engagement and learning culture, all of which were embraced by Costa Rican leaders as they chose, planned and implemented their reforms. ${ }^{31} 34-36$

We found that health leaders' shared and compelling vision for comprehensive PHC was a key facilitating contextual factor for the reform. Setting a clear, compelling vision enabled leaders to mobilise stakeholder commitment. Vision-setting has been a primary driver of large-scale implementations in other settings. ${ }^{32} 3738$ Similarly, strong leadership allowed reformers to implement their vision. For example, to consolidate PHC functions under a single CCSS entity, leaders committed human and financial resources, including re-allocating staff to the TWGs from their routine work. This monumental task could not have been accomplished without strong leadership.

While other Latin American countries implemented health reforms solely in a top-down direction, ${ }^{39}$ Costa Rica's strategy of deep community engagement strengthened their reform by creating transparency and building buy-in. To overcome initial resistance, leaders applied methods described in change management literature, such as providing in-service and preservice training, engaging stakeholders in TWGs, facilitating collaborative workshops and negotiating with unions regarding benefits. ${ }^{31}{ }^{33}$ Literature shows that involving multiple stakeholders in this way can diminish resistance between groups and strengthen support. ${ }^{31} 3240$

Costa Rica had contextual factors important for successful implementation of reform, such as institutional stability, a learning culture and strong leadership. ${ }^{32} 40-42$ While many countries experience shifting political environments that derail major health reforms, the autonomy of the CCSS enabled the reforms to succeed and sustain through multiple political transitions. Similarly, during the preparation phase, Costa Rica health leaders' willingness to learn from other countries and adapt best practices to local contextual factors was an important component of its success. ${ }^{40}{ }^{41} \mathrm{We}$ also found that political commitment was important driver of sustainability. Future studies are need to explore how to build political commitment to drive PHC improvements and sustain them into the future.

There were a number of countries that also have been successful, including some with different approaches (eg, Ghana and Cuba).$^{43}$ However, success has not been uniform across PHC implementations, reflecting in some countries a lack of prioritisation of PHC (eg, Haiti), implementation challenges (eg, Nicaragua and Mozambique) and sustainability challenges after political turnover (eg, Brazil). ${ }^{44-46}$

While Costa Rica's reforms have been largely successful, like many countries such as Ghana, Nigeria and Bangladesh, urban implementation has remained a challenge. ${ }^{47} 48$ This challenge highlights the importance of adaptation as a strategy to account for contextual differences between urban and rural settings. Although not a major theme in our interviews, a recent case study identified other challenges facing Costa Rica that require adaptation, including emerging epidemiological and demographic transitions, as well as a growing migrant population. ${ }^{43}$ Future studies are needed to explore how Costa Rica's implementation strategies and PHC model can be adapted for different contexts.

Our study had several limitations. First, recall bias may be present, given that interviews occurred over 20 years after the reforms. Second, our sample included more KIs from urban than rural settings, so our findings may not fully reflect the rural perspective. We did not include any KIs from the private sector and only two KIs had previous affiliation with the MOH. Finally, reflecting the study aims, we did not explore each reform's successes and challenges; however, this is an important area for future implementation research.

The global community has prioritised achieving UHC by 2030, of which PHC must be a foundational cornerstone. ${ }^{49}$ We describe Costa Rica's road map for PHC improvement from initial exploration through preparation, implementation and sustainment. We show that in addition to many facilitating contextual factors, Costa 
Rica health leaders were intentional in their planning and implementation of the PHC model, which was comprehensive by design, prioritising both individual and population care and prevention within their PHC model. This enabled both initial success and sustainability over time. We believe that these lessons from Costa Rica's experience can help other countries navigate the important but difficult work of strengthening PHC as they work towards UHC.

\section{Author affiliations}

${ }^{1}$ Ariadne Labs, Boston, Massachusetts, USA

${ }^{2}$ Brown University Warren Alpert Medical School, Providence, Rhode Island, USA

${ }^{3}$ Health Service Delivery Strengthening Department, Caja Costaricense de Seguro

Social, San José, Costa Rica

${ }^{4}$ Postgraduate Department, Caja Costaricense de Seguro Social, San José, Costa Rica

${ }^{5}$ Caja Costarricense de Seguro Social, San José, Costa Rica

${ }^{6}$ Division of Global Health Equity, Department of Medicine, Brigham and Women's Hospital, Boston, Massachusetts, USA

${ }^{7}$ Division of General Medicine, Department of Medicine, Brigham and Women's Hospital, Boston, Massachusetts, USA

${ }^{8}$ Department of Medical Social Sciences, Northwestern University Feinberg School of Medicine, Chicago, Illinois, USA

Twitter Lauren Spigel @laurenspigel

Acknowledgements The authors would like to thank the CCSS and key informants for their time and insights, as well as Ami Karlage, Dr Chris van Weel and our other peer reviewers for their review and critical inputs.

Contributors LS: design of the work; analysis and interpretation of data for the work; drafting the work; final approval of the version to be published; agreement to be accountable for all aspects of the work. MP: design of the work; acquisition, analysis and interpretation of data for the work; revising it critically for important intellectual content; final approval of the version to be published; agreement to be accountable for all aspects of the work. OVdC: interpretation of data for the work; revising it critically for important intellectual content; final approval of the version to be published; agreement to be accountable for all aspects of the work. HLR: design of the work; analysis and interpretation of data for the work; revising it critically for important intellectual content; final approval of the version to be published; agreement to be accountable for all aspects of the work. JAJB: interpretation of data for the work; revising it critically for important intellectual content; final approval of the version to be published; agreement to be accountable for all aspects of the work. AMM: interpretation of data for the work; revising it critically for important intellectual content; final approval of the version to be published; agreement to be accountable for all aspects of the work. EZM: interpretation of data for the work; revising it critically for important intellectual content; final approval of the version to be published; agreement to be accountable for all aspects of the work. DS: interpretation of data for the work; revising it critically for important intellectual content; final approval of the version to be published; agreement to be accountable for all aspects of the work. $A B$ : interpretation of data for the work; revising it critically for important intellectual content; final approval of the version to be published; agreement to be accountable for all aspects of the work. LRH: design of the work; interpretation of data for the work; revising it critically for important intellectual content; final approval of the version to be published; agreement to be accountable for all aspects of the work.

Funding The authors have not declared a specific grant for this research from any funding agency in the public, commercial or not-for-profit sectors.

Competing interests None declared.

Patient consent for publication Not required.

Ethics approval The Brown University Institutional Review Board determined that this study was not human subjects research so was exempted.

Provenance and peer review Not commissioned; externally peer reviewed.

Data availability statement Data are available upon request. The qualitative data have not been included as a supplement because this would likely compromise the individual privacy of key informants. Requests for the de-identified qualitative data set can be made by contacting Lauren Spigel (Ispigel@ariadnelabs.org).
Open access This is an open access article distributed in accordance with the Creative Commons Attribution Non Commercial (CC BY-NC 4.0) license, which permits others to distribute, remix, adapt, build upon this work non-commercially, and license their derivative works on different terms, provided the original work is properly cited, appropriate credit is given, any changes made indicated, and the use is non-commercial. See: http://creativecommons.org/licenses/by-nc/4.0/.

\section{ORCID iDs}

Lauren Spigel http://orcid.org/0000-0001-7846-4890

Hannah L Ratcliffe http://orcid.org/0000-0003-4134-5112

Lisa R Hirschhorn http://orcid.org/0000-0002-4355-7437

\section{REFERENCES}

1 UN General Assembly. Political Declaration of the high-level meeting on universal health coverage, 2019. Available: https://undocs.org/en/ A/RES/74/2 [Accessed 20 Nov 2019].

2 DESA. Leaving no one behind. In: The sustainable development goals report 2016. United Nations, 2016: 48-9.

3 Sustainable development goal 3: ensure health lives and promote well-being for all at all ages. United nations sustainable development knowledge platform, 2017. Available: https://sustainabledevel opment.un.org/sdg3 [Accessed 20 Apr 2018].

4 Hone T, Macinko J, Millett C. Revisiting Alma-Ata: what is the role of primary health care in achieving the sustainable development goals? Lancet 2018;392:1461-72.

5 Bitton A, Ratcliffe HL, Veillard JH, et al. Primary health care as a foundation for strengthening health systems in low- and middleincome countries. J Gen Intern Med 2017;32:566-71.

6 Bitton A, Veillard JH, Basu L, et al. The 5S-5M-5C schematic: transforming primary care inputs to outcomes in low-income and middle-income countries. BMJ Glob Health 2018;3:e001020.

7 Macinko J, Starfield B, Erinosho T. The impact of primary healthcare on population health in low- and middle-income countries. J Ambul Care Manage 2009;32:150-71.

8 Kruk ME, Porignon D, Rockers PC, et al. The contribution of primary care to health and health systems in low- and middle-income countries: a critical review of major primary care initiatives. Soc Sci Med 2010;70:904-11.

9 Kluge H, Kelley E, Swaminathan S, et al. After Astana: building the economic case for increased investment in primary health care. Lancet 2018:392:2147-52.

10 The Astana declaration: the future of primary health care? The Lancet 2018:392:1369.

11 van den Muijsenbergh $\mathrm{M}$, van Weel $\mathrm{C}$. The essential role of primary care professionals in achieving health for all. Ann Fam Med 2019;17:293-5.

12 Starfield B, Shi L, Macinko J. Contribution of primary care to health systems and health. Milbank Q 2005;83:457-502.

13 Kidd M. The contribution of family medicine to improving health systems. 2nd edn. London: Radcliffe Publishing Ltd, 2013.

14 World Health Organization,, United Nations Children's Fund. Declaration of Astana. World Health Organization and United Nations Children's Fund, 2018.

15 Commission on Social Determinants of Health. Closing the gap in a generation: health equity through action on the socialdeterminants of health. 40. World Health Organization, 2008.

16 Clark MA. Health sector reform in Costa Rica: reinforcing a public system. Washington DC: Woodrow Wilson Center Workshops on the Politics of Education and Health Reforms, 2002.

17 Pesec M, Ratcliffe $\mathrm{H}$, Bitton A, et al. Building a thriving primary health care system: the story of Costa Rica 2017.

18 Unger J-P, De Paepe P, Buitrón R, et al. Costa Rica: achievements of a heterodox health policy. Am J Public Health 2008;98:636-43.

19 World Bank Group. Costa Rica - Health Sector Reform - Social Security System Project - Staff Appraisal Report 1993.

20 Hirschhorn LR, Langlois EV, Bitton A, et al. What kind of evidence do we need to strengthen primary healthcare in the 21 st century? BMJ Glob Health 2019;4:e001668.

21 Moullin JC, Dickson KS, Stadnick NA, et al. Systematic review of the exploration, preparation, implementation, Sustainment (EPIS) framework. Implement Sci 2019;14:1.

22 Lee T, McKee D. An empirical evaluation of devolving administrative control to Costa Rican hospital and clinic directors. Int $J$ Health Serv 2015:45:378-97.

23 Muiser J. La Gobernanza del sector Salud Costarricense PostReforma Y SU Incidencia en EI Cumplimento del Derecho a la Salud: Tesis sometida a la consideración de la Comisión del Programa de 
Estudios de Posgrado Doctorado de Gobierno Y Políticas Públicas para optar. San José: Ciudad Universitaria Rodrigo Facio, 2015.

24 Pesec M, Ratcliffe HL, Karlage A, et al. Primary health care that works: the Costa Rican experience. Health Aff 2017;36:531-8.

25 Prado A, Rodríguez P, Salas A. Innovation in the public sector: the Costa Rican primary healthcare model. HMPI 2019;4.

26 World Bank Group. DataBank. DataBank. Available: https:// databank.worldbank.org/home.aspx [Accessed 10 Nov 2019].

27 Aarons GA, Hurlburt M, Horwitz SM. Advancing a conceptual model of evidence-based practice implementation in public service sectors. Adm Policy Ment Health 2011;38:4-23.

28 Rosero-Bixby L. Spatial access to health care in Costa Rica and its equity: a GIS-based study. Soc Sci Med 2004;58:1271-84.

29 Caja Costarricense Seguro Social. Memoria Institucional 2018. San Jose, Costa Rica: Caja Costarricense de Seguro Social, 2019.

30 Vargas JR, Muiser J. Promoting universal financial protection: a policy analysis of universal health coverage in Costa Rica (19402000). Health Res Policy Syst 2013;11:28.

31 Deming WE. Out of the crisis. The MIT Press 1986.

32 Perla RJ, Bradbury E, Gunther-Murphy C. Large-Scale improvement initiatives in healthcare: a scan of the literature. J Healthc Qual 2013;35:30-40.

33 Kotter JP, Schlesinger LA. Choosing strategies for change. Harv Bus Rev 1979;57:106-14.

34 Juran JM. The quality trilogy: a universal approach to managing for quality. Quality Progress 1986:19-24.

35 Anderson JC, Rungtusanatham M, Schroeder RG. A theory of quality management underlying the Deming management method. Acad Manage Rev 1994;19:472-509.

36 Kotter JP. Leading change. Vahlen 2011.

37 Palaia A, Spigel L, Cunningham M, et al. Saving lives together: a qualitative evaluation of the saving mothers, giving life public-private partnership. Glob Health Sci Pract 2019;7:S123-38.

38 Kruk M, Leslie H, Pate M. High-Quality health systems in the sustainable development goal era: a special collection. speaking of medicine community Blog, 2017. Available: http://blogs.plos.org/ speakingofmedicine/2017/12/13/high-quality-health-systems-in-thesustainable-development-goal-era-a-special-collection/ [Accessed 31 Jul 2018].

39 Homedes N, Ugalde A. Human resources: the Cinderella of health sector reform in Latin America. Hum Resour Health 2005;3:1.

40 Berman PA, Bossert TJ. Appraising a decade of health sector reform in developing countries. United States Agency for International Development, 2000.

41 Kruk ME, Gage AD, Arsenault C, et al. High-Quality health systems in the sustainable development goals era: time for a revolution. Lancet Glob Health 2018;6:e1196-252.

42 Roberts MJ, Hsiao W, Reich M. Getting Health Reform Right : A Guide to Improving Performance and Equity. Oxford University Press, 2008.

43 Primary Health Care Performance Initiative. Improvement strategies. strategies for improving primary health care, 2018. Available: https:// improvingphc.org/improvement-strategies [Accessed 18 Dec 2019].

44 Gage AD, Leslie HH, Bitton A, et al. Assessing the quality of primary care in Haiti. Bull World Health Organ 2017;95:182-90.

45 Magnussen L, Ehiri J, Jolly P. Comprehensive versus selective primary health care: lessons for global health policy. Health Aff 2004;23:167-76.

46 Castro MC, Massuda A, Almeida G, et al. Brazil's unified health system: the first 30 years and prospects for the future. Lancet 2019;394:345-56.

47 Adongo PB, Phillips JF, Aikins M, et al. Does the design and implementation of proven innovations for delivering basic primary health care services in rural communities fit the urban setting: the case of Ghana's community-based health planning and services (CHPS). Health Res Policy Syst 2014;12:16.

48 Elsey H, Agyepong I, Huque R, et al. Rethinking health systems in the context of urbanisation: challenges from four rapidly urbanising low-income and middle-income countries. BMJ Glob Health 2019:4:e001501.

49 Binagwaho A, Adhanom Ghebreyesus T. Primary healthcare is cornerstone of universal health coverage. BMJ 2019;365:I2391. 